\title{
Preventing and lessening exacerbations of asthma in school age children associated with a new term: pleasant
}

Steven Julious, Michelle Horspool

From 2nd Clinical Trials Methodology Conference: Methodology Matters

Edinburgh, UK. 18-19 November 2013

We will present the PLEASANT trial: a relatively novel cluster randomised cohort clinical trial in primary care where GP practices (140) are randomised to a NHS delivered public health intervention or usual care. The outcome data is routine clinical data collected through the Clinical Practice Research Datalink.

The motivation for PLEASANT is a pronounced increase in the number of unscheduled visits to the doctor, by school aged children with asthma around the return back to school in September. This increase is preceded by a drop in the number of prescriptions administered in August. It is possible therefore that children might not be taking their medication as they should just prior to the challenge they get on return back to school from mixing with children when they picking up infections which might affect their asthma. Indeed children with asthma are approximately twice as likely to have unscheduled medical contacts compared to non-asthmatic children in September following return to school.

In the trial school aged children with asthma will be randomised to receive a letter from their GP or usual care. The letter will be sent prior to the start of school holidays reminding of the importance of medication adherence. The aim is to reduce exacerbations of asthma and unscheduled contacts, in school aged children.

Recruitment of sites started in Jan 2013. We will describe the PLEASANT trial and the merits of the design chosen. We will also present results on factors which influence recruitment of centres into a trial.

Published: 29 November 2013

University of Sheffield, Sheffield, UK

(c) 2013 Julious and Horspool; licensee BioMed Central Ltd. This is an Open Access article distributed under the terms of the Creative Commons Attribution License (http://creativecommons.org/licenses/by/2.0), which permits unrestricted use, distribution, and reproduction in any medium, provided the original work is properly cited.
doi:10.1186/1745-6215-14-S1-P17

Cite this article as: Julious and Horspool: Preventing and lessening exacerbations of asthma in school age children associated with a new term: pleasant. Trials 2013 14(Suppl 1):P17.

Submit your next manuscript to BioMed Central and take full advantage of:

- Convenient online submission

- Thorough peer review

- No space constraints or color figure charges

- Immediate publication on acceptance

- Inclusion in PubMed, CAS, Scopus and Google Scholar

- Research which is freely available for redistribution Submit your manuscript at
www.biomedcentral.com/submit C Biomed Central 